\title{
培養グリオーマ細胞水溶性蛋白分画の二次元電気泳動法による 解析
}

特に PCNAについて

本田 千穂・田淵 和雄*·西本 詮

Analysis of the Water-soluble Protein Fraction of Glioma Cells by Two-dimen-
sional Electrophoresis

Chiho Honda, Kazuo TABUCHI* and Akira Nishimoto

Department of Neurological Surgery, Okayama University, Okayama; *Department of Neurological Surgery, Saga Medical School, Saga

\begin{abstract}
The authors analyzed water-soluble proteins of cultured human and rat glioma cells by twodimensional polyacrylamide gel electrophoresis methods. Glioma cells were suspended in distilled water and then destroyed by freezing and thawing to obtain the water-soluble protein fractions. A modification of O'Farrell's non-equilibrium $\mathrm{pH}$ gradient (NEPHGE) method was used to analyze differences in protein mapping. Manabe's microscale two-dimensional electrophoresis without denaturing agents was used to detect proliferating cell nuclear antigen (PCNA/cyclin) by Western blotting. With O'Farrell's NEPHGE method and silver staining, at least 200 different polypeptides were clearly identified in each cell line. Cytoskeletal proteins, such as actin, were consistently separated in all cell lines. Marked differences in the protein map were observed between human and rat glioma cell lines, and even within the same species. Presumably, these differences are attributable to cell-biological difference in the glioma cell lines. Some proteins that were prominent in proliferating cells were scant in the protein maps of cells cultured for 24 hours in medium not containing calf serum, which suppresses cell growth. PCNA, an acidic nuclear protein that appears only in the late $\mathrm{G}_{1}$-S phase and is believed to be involved in cell proliferation, was detected by Western blotting and indirect immunostaining. Quantitative analysis of PCNA spots on the protein map appears useful in assessment of glioma cell proliferation. These results indicate that twodimensional polyacrylamide gel electrophoresis can contribute to the understanding of the biological features of glioma cells.
\end{abstract}

Key words: two-dimensional electrophoresis, experimental glioma, water-soluble protein, proliferating cell nuclear antigen

I はじめに

グリオーマの細胞生物学的特性を明らかにすることは， グリオーマに対するよりよい診断方法や治療法を考兄る上
できわめて重要なことと思われる。この上らな試みの一つ として，二次元電気泳動法によるグリオーマの蛋白分画の 解析が考之られる。すなわち，グりオーマが有する種々の 蛋白の解析を行うことにより，グリオーマに特異的な腫瘍 
抗原，グリオーマ細胞の代謝あるいは成長の制御に関連す ると考えられる諸因子などの同定が可能之なってくるもの 之思われる.今回，二次元電気泳動法を用いて培養グリオ 一マ細胞の水溶性蛋白分画の解析を試み大結果，グリオー マの特性を理解する上で興味ある知見を得たので報告す る.

\section{III材料および方法}

\section{1. 材料}

細胞は，当教室でヒトグリオブラストーマ㱏例より確立 され，継代維持されている $\mathrm{KY}$ 細胞占，势よび Ponten ら ${ }^{19}$ Kよりヒトグりオーマ症例より樹立された118 MG 紐 胞を Rous sarcoma virusで transform した KC 細胞，また

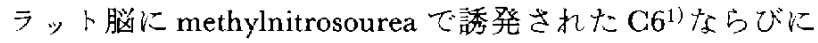
9L 20 細胞を用いた。細胞は，10\%牛胎児血清怙よび抗生 物質を含吉 Eagle's minimun essential medium (MEM) 培 養液とし， $37^{\circ} \mathrm{C} ， 5 \%$ 炭酸ガス中で静置培養を行った。細 胞增殖後，培盖液を除去し， phosphate buffered saline (PBS) で 2 回洗滌したのち, 細胞を蒸留水中に機械的に浮 遊させ，この細胞浮遊液の凍結融解を繰り返すことによっ て細胞の水溶性蛋白分画を得た。細胞の不溶性蛋白分画は $5000 \mathrm{rpm} ， 15$ 分の遠沈により除去し，上清の水溶性蛋白 分画を凍結乾燥によって10 $\mu \mathrm{g} / \mu l$ の蛋白濃度に濃縮して試 料とした。 小た，細胞增殖後，血清を含まないMEM 中 にて24時間培盖を続け，増殖が停止したと思われる培着グ リオーマ細胞についても同様に水溶性蛋白分画を抽出し,

試料とした。

\section{O'Farrell 法}

各培養グリオーマ細胞株間での蛋白質地図の比較検討に は, O'Farrell ら ${ }^{16,17)}$ の方法に準したた二次元電気泳動法を 行った。すなわち, 一次元目は直径 $2.5 \mathrm{~mm}$, 長さ $12 \mathrm{~cm}$, $2 \%$ ampholine ( $\mathrm{pH} 3.5 \sim 10, \mathrm{LKB}), 9 \mathrm{M}$ 尿素, $2 \% \mathrm{NP} 40$ 含都 polyacrylamide gel 索用い, O'Farrell ら equilibrium pH gradient (NEPHGE) 法によって1600 Vhr

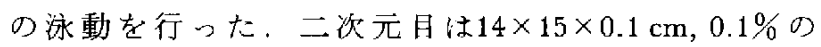
sodium dodecyl sulfate (SDS) t含を8１5\%密度勾配 polyacrylamide gel 至用いた。泳動終了後，銀染色キッ门 （第一化学薬品）を使用して銀染色を行い，各蛋白スポット の量的ならびに質的差異の比較検討を行ったななお、アク チンスポットの同定は，精製されたアクチン(Sigma)を試 料の泳動と同条件で試料と同時に泳動することによって行 った。ささらに，分子量は molecular weight marker オリェ ント醭母)の泳動上比較することによって同定した。

\section{3. 真鍋法}

ウェスタンンブロッティング一免疫染色には，真鍋ら ${ }^{10)} の$
変性剤をまったく含まないミク口二次元電気泳動法を用い た，すなわち，ミク口多検体二次元電気泳動装置(富士理 研社)を用いて，一次元目は直径 $1.3 \mathrm{~mm}$ ，長さ $35 \mathrm{~mm}, 2 \%$ ampholine $(\mathrm{pH} 3.5 \sim 10), 0.5 \%$ ampholine $(\mathrm{pH} 3.5 \sim 5)$ t含 导 polyacrylamide gel で等電点電気泳動を行った，二次元

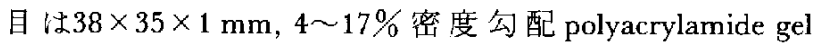
を用いた，泳動終了後，gel の銀染色を行5とと女に，同 時に泳動した gel上り水平型トランスファーブロッティン グ装置 $(\mathrm{OMY}-1$ 型，富士理研社)を用いて蛋白をニトロセ ルロース膜へ転写した。ブロッティング後のニトロセルロ 一又膜は，免疫染色を行って增殖性細胞核抗原(PCNA)の 同定を行った。すなかち，3\% bovine serum albumin を含 むPBS 中で室温にて 2 時間振盜して残存蛋白結合部位を マスクしたのち，抗 PCNA 血清 $(\times 250$, Dr. Tan, Scripps Clinic and Research Foundation, La Jolla, Calif., USA 供与を受けた)と一晚反応させた。コントロールには正常 ヒト血清と反応させたもの，およびブロッティング後 $56^{\circ} \mathrm{C} ， 30$ 分間の加熱により PCNAを不活化したのち24), 抗 PCNA 血清と反応させたものを用いた，PBSで洗滥後， peroxidase-conjugated rabbit anti-human IgG $(\times 200$, DAKO) と 1 時間反応させ，PBSで洗滌したのち，発色は $0.003 \% \mathrm{H}_{2} \mathrm{O}_{2}$ 加 $2 \mathrm{mM}$ diaminobenzidine 溶液で約 3 分間 行った ${ }^{26)}$.

\section{III 結果}

1. O'Farrell 法

この方法により，いずれの細胞株に扣いても約200種の

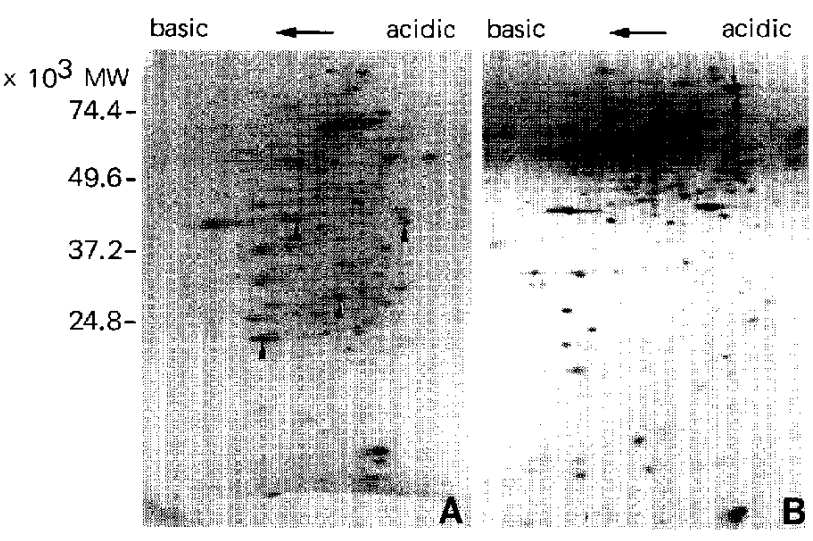

Fig, 1 Two-dimensional electropherograms of the water-soluble protein fraction of rat 9L (A) and C6 (B) tumor cells by O'Farrell's method. ${ }^{16,17)}$ arrowheads: protein spots more prominent in $9 \mathrm{~L}$ cells, vertical arrows: protein spots more prominent in $\mathrm{C} 6$ cells. MW indicates molecular weight. 

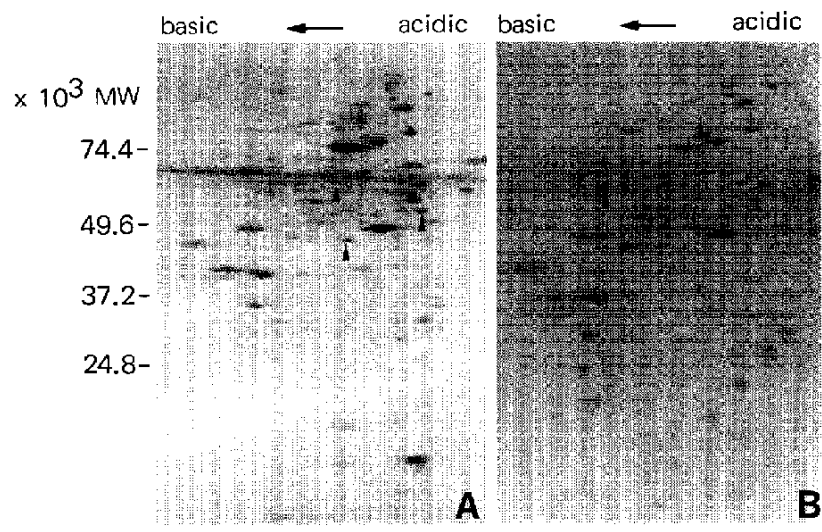

Fig. 2 Two-dimensional electropherograms of the water-soluble protein fraction of human $\mathrm{KY}$ (A) and $\mathrm{KC}$ (B) glioma cells by O'Farrell's method. arrowheads: protein spots more prominent in $\mathrm{KY}$ cells, vertical arrows: protein spots more prominent in $\mathrm{KC}$ cells.

蛋白(ポリペプチド)が分離可能であり(Fig. 1，2），しかも 個々の細胞株について，それぞれ高い再現性が得られた。 各細胞株から得られた蛋白質地図を比較検討してみると， アクチンを初め上する細胞骨格蛋白などは各細胞株に共通 に認められたが，ヒトグリオーマ細胞株とラットグリオー マ細胞秼間，またヒトグリオーマ細胞株相互間，ラットグ リオーマ細胞株相互間でも多数の蛋白スポット炕質的およ び量的差異が認められた。たとえば，ラット9L 細胞で は，Fig. 1AK arrowheadで示したよらに，分子量 $40 \times 10^{3}$ 以下の比較的低分子領域に他の細胞株にはみられない多数 の蛋白スポットが検出された。一方，C6 細胞では，Fig 1Bに arrow で示したように，比較的高分子領域で他の細 胞株との差が著明であった。ヒト KY 細胞と $\mathrm{KC}$ 細胞の 蛋白質地図は注济同様のパターンを示し，両者の差異は主 として量的なものであった。すなおち，Fig. 2A に arrowheadで示したよらにKY細胞に多いものと，Fig. 2BK arrowで示したように KC 細胞に多いものとがあった。

\section{2. 真鍋法}

この力法では，銀染色に上り䄪50種の蛋白が分離可能で あった(Fig. 3). 対数増殖中の細胞 (Fig. 3A) と無血清 MEM 中に置いて增殖を停止させた細胞 (Fig. 3B) 上で蛋 白質地図を比較してみると，無血清 MEM 中に圈いた細 胞では分子量 $35 \times 10^{3}$, 等電点 5 付近のスポット (arrowhead）を初め，arrowで示したように数個の蛋白の明らか な減少あるいは消失が認められた。これらの蛋白スポット のなかにPCNAが含本れているか否かを検索する目的 で，前述したブロッティング一免疫染色法を試みた．Fig. $4 \mathrm{~A}$ に示すごとく，抗 PCNA 血清と反応させた二トロセル

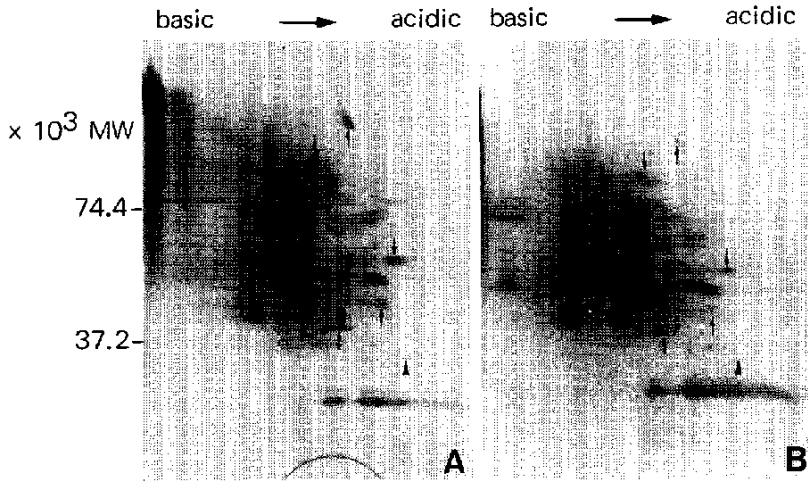

Fig. 3 Two-dimensional electropherograms of the water-soluble protein fraction of human KY glioma cells by Manabe's method. ${ }^{10)}$ A: proliferating cells, B: nonproliferating cells cultured for 24 hours in medium not containing calf serum. vertical arrows: protein spots diminished in non-proliferating cells, arrowhead: proliferating cell nuclear antigen (PCNA)

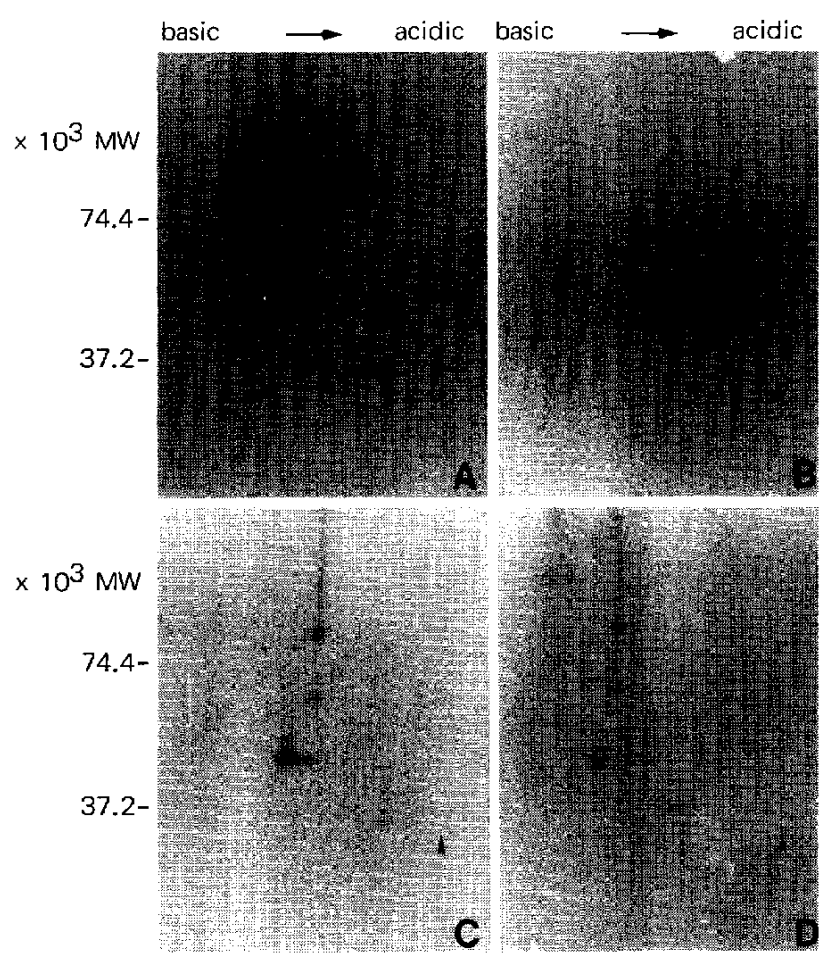

Fig. 4 Two-dimensional electropherograms stained by the indirect immunoperoxidase method after Western blotting of the water-soluble protcin fraction of human KY glioma cells by Manabe's method. A: proliferating cells (anti-PCNA serum), B: proliferating cells (normal human serum), C: proliferating cells (inactivation at $56^{\circ} \mathrm{C}$ for 30 minutes, anti-PCNA serum), D: nonproliferating cells (anti-PCNA serum). arrowhead: PCNA. 
ロース膜ではコントロール血清との反応(Fig. 4B)ではみ ら扎ないポットが検出された。これらのスポットのら ち,ブロッティングした蛋白を $56^{\circ} \mathrm{C} ， 30$ 分間の熱処理によ ってPCNA の抗原性を不活化したのち抗 PCNA 抗体と反 応させた場合（Fig.4C），また無血清 MEM中に置いて増 殖を停止させた細胞の水溶性蛋白分画について抗 PCNA 抗体を反纯さ世上場合 (Fig. 4D) には分子量 $35 \times 10^{3}$, 等電 点 5 付近のスポットの染色仕認められず, このスポットの 蛋白が PCNAであると考交られた。

\section{$\mathbf{N}$ 考察}

polyacrylamide gel二次元電気泳動法は，1975年の $\mathrm{O}^{\prime}$ Farrell ${ }^{16)}$ の報告以来，高度な分離能と良好な再現性を有 するため，種々の蛋白の分析に応用されている。一般に蛋 白媔は電荷と分子量といら互いに独立した二つの性質を持 っているため，電荷と分子量との差による分離を同時に行 えば，それぞれ単一の蛋白を検出あるい性分離することが 可能である。今回用いた O'Farrell 法16,17は，一次元目に NEPHGE，二次元目にSDS gel slab電気泳動孛組文合女 た二次元電気泳動法であり，高い分離能が得られるが，高 濃度の尿菜やSDSを用いるため，泳動された蛋白質の高

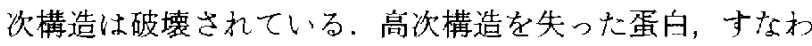
らポりペプチドは酵素活性などの生理活性を失っているこ とが多く，生理活性を持った蛋白の検索にはO'Farrell 法

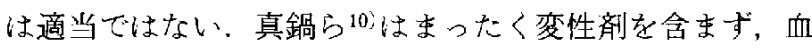
清蛋白質や組織の水溶性蛋白質を native な状態で分離す ることのできる二次元電気泳動法を開発し，O'Farrell 法 で得られるパーンをポリペプチド地図，彼らの方法で得 られるパターンを蛋白質地図と呼んで区別与べきであると している12)。しかし，一般に性 O'Farrell 法で得られるパ ターンも蛋白質地図と呼ばれることが多い，今回，各細胞 株の蛋白質の比較検討には O'Farrell 法を，PCNA の免疫 化学的検索には真鍋法を用いた。

今回試料とした蛋白質は，いずれも株化された細胞集団 から得られたものであり，展開された電気泳動パターン (蛋白質地図)は，それぞれの紐胞の性質の差を直接反映し ているるのと考光られる。ヒト細胞株とラット細胞株間て の蛋白質地図の差は，量的のみならず質的にる明らかで， これらのなかには種差による細胞構成蛋白の違いも含まれ ているものと思われる。しかし，ラット9L 細胞では特に 他の細胞株との蛋白質地図の質的差異が著明で，これは 9L 細胞が真のグリオーマではなく，グリオサルコーマの 性格を持った細胞株であること20)と関係があるかもしれな い。すなわわ，腫瘍の組織型によって蛋白質地図に大きな 差異が現れる可能性が考光られる。言い换えれば，それぞ
れの組織型によって独特な蛋白質が発現されているものと

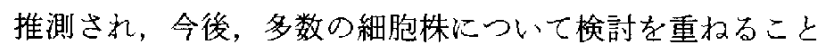
により，蛋白質ハターンと腫易の組織型との関俰を明らか にできるのではないかと考えられる。

さて，個々のグリオーマの細胞生物学的悪性度は多様で あり，それぞれのグリオーマについて，その增殖能を正確 に把握しておくことは，グリオーマ患者の治療法の選択や 予徭の推定を行ら上できわめて重要であると言える。從 来, グリオーマの増殖能の検索には ${ }^{3} \mathrm{H}$-thymidine $の$ 標識 率 (labeling index $)^{8,9)}$ や分裂指数 (mitotic index)などが用い られてきた。最近ではGratzner thymidine analogue である bromodeoxyuridine (BrdU)に対 するモノクローナル抗体を用いる力法がグリオーマの增殖 能の解析に試双られつつある 内に DNA 合成中の細胞に取り込まれたBrdUをモノク口 ーナル抗体を用いて検出するものですり，日常臨床への応 用は必ずしも容易ではないしたがって，グリオーマの増 殖能を判定するより直接的な方法としては，もともと増殖 中の細胞にの及発現されている物質を検出すること上考光 られ，著者らはPCNAに注目してきている。

抗 PCNA 抗体は，1978年，Miyachi ら ${ }^{14)}$ にって全身 性エリテマトーデス (SLE) 患者の一部の血清中に抗核自己 抗体として検出されたわので，冬の後の研究により， PCNA は増殖中の細胞の核内に特異的に出現することが 明らかにされた23)。最近ではPCNAは，1980年，Bravo らによって発見され， cyclin と命名された蛋白質と同一 の蛋白質であることが判明している゙ 分子量33 36 $\times 10^{3}$, 等電点4.8４.90非ヒストン性酸性核 蛋白であり，その抗原性は56 ${ }^{\circ} \mathrm{C} ， 30$ 分間の加熱で不活化 され24), 最近ではそのアミ，酸配列の一部子明らかにされ ている18)。主た，PCNAは動物種とは関係なく，乙かも 正常あるいは腫瘜細胞を問わず，細胞増殖期，特にlate $G_{1} \sim S$ 期の細胞の核内に特異的に発現され，細胞の DNA 合成に深く関与しているものと考兄られている3 . PCNA はこのような特性を持っているため，各種覀性腫瘍の診断 に抗 PCNA 抗体を用い上5とする試みが散見される

そこで，著者らは培養グリオーマ細胞执よび開頭術によ って得られたヒトグリオーマ生検組織に就けるPCNAの 発現老抗 PCNA 抗体を用いて間接酵素抗体法により検索 した21,22)，その結果，各種グリオーマにおける PCNA 陽 性細胞の割合はこれまで報告されているBrdUあるいは ${ }^{3} \mathrm{H}$-thymidine の標識率 ${ }^{7}$ とよく一致していることが判明 した。したがって，PCNAはダリオーマの増殖能を推定 する上でよい指標となりらると考えられる。しかし，ヒト グリオーマ組織で免疫組織化学的に PCNA を検出するに 
は難点もある．SLEに㧍ける抗 PCNA 抗体の出現頻度は 約 $2 \%$ しかなく ${ }^{14)}$ ，十分な量の抗体を得ることは容易では ない。また，ヒトグリオーマ組織に拁いて免疫組織染色を 間接法で行ら場合，二次抗体である抗七トIgG抗体は組 織中心含まれているIgGとも反応してしまい，陽性反応 を確認しにくい欠点が女る。ところが，今回行ったよらに グリオーマ蛋白の二次元電気泳動によって分離した蛋白に ついて免疫染色を行充ば，PCNAのみを検出することが 可能である。また，これによって䤵染色による蛋白質地図 上のPCNAスポット定同定すれば，二次元電気泳動一銀 染色のみに上ってPCNAの検出が可能となる，さらにま た，二次元電気泳動に上る蛋白質地図上の各スポットは， 大きさと染色濃度により量的情報も含んでいるのが特徵で ある、そこで，たとえばュンピューターによる解析を加兄 れば11)，PCNAの半定量化も可能となる。したがって， 種々のグリオーマの蛋白質の二次元電気泳動を行い，その PCNA スポットの量を検討することにより，グリオーマ の增殖能の程度を容易に推定できるようになるものと考え られる。

\section{$\mathrm{V}$ ¿ め}

ヒト执よびラット培養グリオーマ細胞の水溶性蛋白分画 を二次元電気泳動法によって解析した．＇Farrell 法によ る二次元電気泳動 gelについて銀染色を行った結果, 䄪 200種の蛋白スポットが分離可能であり，ヒトグリオーマ 細胞株とラットグリオーマ細胞株間のみならず，ヒトグリ オーマ細胞株相互間，ラットグリオーマ細胞株相互閒にも 蛋白質の質的あるいは量的差異が認められた。これらの差 異のなかにはダリオーー細胞の細胞生物学的特性の差異に 基つくものも西ると思呩机，二次元電気泳動法に上る蛋白 分画の解析はグリオーマの細胞生物学的特性の検索にも有 用な方法となるものと考兄られる。また，蛋白質変性剤を 含まない系での二次元電気泳動法(真鍋法)似引き続き，二 トロセルロース膜へのウェスタンブロッティング倦, 特定 の蛋白質に対する特異抗体を用いた免疫染色を行らことに より，蛋白質の同定が可能であった．今回，こらして同定 Lた PCNA は late $\mathrm{G}_{1} \sim \mathrm{S}$ 期の細胞核内侍異的に出現す る蛋白質であることから，二次元電気泳動法を用いて PCNAの量的变化を観察することにより，今後，グリオ 一マ細胞の增殖能の程度を容易に推定できるよらになるも の上考えられる。

本論文の要旨は，第44回(1985年10月，長崎) 㧍よび第 45 回 (1986年10月，東京) 日本脳神経外科学会総会において発表した。

\section{文献}

1) Benda P, Lightbody J, Sato G, Sweet W: Differentiated rat glial cell strain in tissue culture. Science 161: 370-371, 1968

2) Bravo R, Celis JE: A search for differential polypeptide synthesis throughout the cell cycle of HeLa cells. J Cell Biol 84: 795802,1980

3) Celis JE, Celis A: Cell cycle dependent variations in the distribution of the nuclear protein cyclin (proliferating cell nuclear antigen) in cultured cells: Subdivision of S phase. Proc Natl Acad Sci USA 82: 3262-3266, 1985

4) Chang PK, Frakes R, Tan EM, Brattin MG, Smetana K, Busch $\mathrm{H}$ : Indirect immunofluorescence studies of proliferating cell nuclear antigen in nucleoli of human tumor and normal tissues. Cancer Res 43: 3770-3777, 1983

5) Gratzner HG: Monoclonal antibody to 5-bromo- and iododeoxyuridine: A new reagent for detection of DNA replication. Science 218: 474-476, 1982

6) 本田千穂, 田淵和雄, 入江恵子, 福岡高宏, 三野章吳, 吉 岡純二, 植田清隆, 大本堯史：培責グリオーマ細胞に及ぼす forskolin $の$ 影響. 神経化学 24: 223-225, 1985

7) Hoshino T, Nagashima T, Murovic JA, Wilson CB, Edwards MSB, Gutin PH, Davis RL, DeArmond SJ: In situ cell kinetics studies on human neuroectodermal tumors with bromodeoxyuridine labeling. $J$ Neurosurg 64: 453-459, 1986

8) Hoshino $T$, Wilson CB: Cell kinetic analysis of human malignant brain tumors (gliomas). Cancer 44: 956-962, 1979

9) Johnson HA, Haymaker WE, Rubini JR, Fliedner TM, Bond VP, Cronkite EP, Hughes WL: A radiographic study of a human brain and glioblastoma multiforme after in vivo uptake of tritiated thymidine. Cancer 13: 636-642, 1960

10) Manabe T, Hayama E, Okuyama T: Microscale multisample two-dimensional electrophoresis of proteins in human serum, cerebrospinal fluid, and urine. Clin Chem 28: 824-827, 1982

11) Manabe T, Okuyama T: Quantitative analysis of two-dimensional electropherograms with a television camera-microcomputer system. J Chromatogr 264: 435-443, 1983

12）真鍋 敬，奥山典生：二次元電気泳動法。ぶんせき 12 : 941-947, 1983

13) Mathews MB, Bernstein RB, Franza BR, Garrels JI: Identity of the proliferating cell nuclear antigen and cyclin. Nature 309: 374-376, 1984

14) Miyachi K, Fritzler MJ, Tan EM: Autoantibody to a nuclear antigen in proliferating cells. $J$ Immunol 121: 2228-2234, 1978

15）長島 正，星野孝夫：5-Bromodeoxyuridine (BrdU)を用い たヒト中权神释系腫瘍の成長解析。脳之神 37: 1195-1201, 1985

16) O'Farrell $\mathrm{PH}$ : High resolution two-dimensional electrophoresis. $J$ Biol Chem 250: 4007-4021, 1975

17) O'Farrell PZ, Goodman HM, O'Farrell PH: High resolution two-dimensional electrophoresis of basic as well as acidic proteins. Cell 12: 1133-1142, 1977 
18) Ogata K, Ogata $Y$, Nakamura RM, Tan EM: Purification and $\mathrm{N}$-terminal amino acid sequence of proliferating cell nuclear antigen (PCNA)/cyclin and development of ELISA for anti-PCNA antibodies. $J$ Immunal 135: 2623-2627, 1985

19) Ponten J, Macintyre EH: Long term culture of normal and neoplastic human glia. Acta Path Microbiol Scand 74: 465-486, 1968

20) Schmidek HH, Nielsen SL, Schillei AL, Messer J: Morphological studies of rat brain tumors induced by $\mathrm{N}$-nitrosomethylurea. $J$ Neurosurg 34: 335-340, 1971

21）田淵和雄, 本田千穂, 中根一穗：グリオーマの悪性度猃断 における増殖性細胞核抗原(PCNA)の有用性。医のあゆ 137: $319-320,1986$

22) Tabuchi $K$, Honda C, Nakane PK: Demonstration of proliferating cell nuclear antigen (PCNA/cyclin) in glioma cells. Neurol Med Chir (Tokyo) 27: 1-5, 1987

23) Takasaki Y, Deng JS, Tan EM: A nuclear antigen associated with cell proliferation and blast transformation. Its distribution in synchronized cells. $J$ Exp Med 154: 1899-1909, 1981

24) Takasaki Y, Fishwild D, Tan EM: Characterization of antigen recognized by autoantibodies in lupus sera. $J$ Exp Med 159: 981992,1984

25) Takasaki Y, Robinson WA, Tan EM: Proliferating cell nuclear antigen in blast crisis of patients with chronic myeloid leukemia. JNCI 73: 655-661, 1984

26) Towbin H, Staehelin $T$, Gordon J: Electrophoretic transfer of proteins from polyacrylamide gels to nitrocellulose sheets: Procedure and some applications. Proc Natl Acad Sci USA 76: 43504354,1979

[別刷請求先：テ769-16 香川県三豊郡豊浜町姫浜708，三豊総合 病院脳神経外科, 本田千䄃] 